Relations industrielles

Industrial Relations

\title{
The Future of Employers' Associations
}

\section{Jean-Pierre Després}

Volume 1, numéro 2, octobre 1945

URI : https://id.erudit.org/iderudit/1023901ar

DOI : https://doi.org/10.7202/1023901ar

Aller au sommaire du numéro

\section{Éditeur(s)}

Département des relations industrielles de l’Université Laval

\section{ISSN}

0034-379X (imprimé)

1703-8138 (numérique)

Découvrir la revue

Citer cet article

Després, J.-P. (1945). The Future of Employers' Associations. Relations

industrielles / Industrial Relations, 1(2), 5-5. https://doi.org/10.7202/1023901ar

Tous droits réservés @ Département des relations industrielles de l’Université Laval, 1945
Ce document est protégé par la loi sur le droit d'auteur. L'utilisation des services d'Érudit (y compris la reproduction) est assujettie à sa politique d'utilisation que vous pouvez consulter en ligne.

https://apropos.erudit.org/fr/usagers/politique-dutilisation/ 


\section{Atelier syndical (Union Shop) imparfait}

C'est une convention par laquelle l'employeur s'engage à congédier les membres actuels ou futurs du syndicat signataire, dès que cesse leur affiliation, et à obliger, sous peine de renvoi, tous les nouveaux employés à devenir membres du syndicat dans un temps limité après le début de leur emploi, et cela, pour la durée de la convention.

Remarque : On dit que cet atelier syndical est imparfait parce que dans ce cas, les travailleurs déjà à l'emploi de l'entrepreneur, et qui ne sont pas membres du syndicat lors de la signature de la convention, ne sont pas obligés de le devenir sous peine d'être congédiés. En vertu de cette clause, il peut fort bien arriver qu'un certain nombre de vieux employés demeurent en dehors du syndicat ; l'atelier n'est donc pas entièrement syndiqué. Quand on a affaire à une entreprise dans laquelle le mouvement des travailleurs est très considérable, après quelques années, si la convention est renouvelée avec la même clause, cet atelier syndical imparfait se transforme par la force des choses en atelier syndical parfait.

\section{Maintien d'affiliation (Maintenance of Mem- bership)}

C'est une clause par laquelle l'employeur s'engage à congédier les membres actuels ou futurs du syndicat signataire, s'ils en venaient à rompre leur affiliation.

Remarque: Dans ce cas, personne n'est obligé de devenir membre du syndicat ni à l'occasion de son emploi ni durant son emploi. Si un travailleur désire joindre le syndicat, il le fait avec pleine et entière liberté, mais une fois qu'il en est devenu membre, il est obligé de le demeurer pendant la durée de la convention.

\section{Préférence syndicale (Preferential Shop)}

C'est un engagement d'honneur par lequel l'employeur convient de donner la préférence aux membres du syndicat signataire en des matières telles que promotions, embauchage, congédiement, réemploi, etc.

Remarque: Une telle clause ne contient aucune obligation stricte. L'employeur ne force personne à faire quoi que ce soit ; il ne fait que montrer ses bonnes dispositions envers le syndicat en favorisant ses membres quand l'occasion se présente.

\section{Retenue syndicale (Check-off)}

C'est une clause par laquelle l'employeur s'engage à déduire les cotisations syndicales du salaire des employés et à les remettre au trésorier du syndicat.

Remarque: Cette déduction peut être facultative ou obligatoire. Elle est facultative lorsque l'employeur exige de chacun des employés une procuration signée. Elle est obligatoire lorsqu'elle est mise en vigueur par la seule signature de la convention. La forme facultative est la seule qui soit légale. De plus, cette forme est révocable ou irrévocable. On dit qu'elle est révocable, quand le travailleur qui a signé une procuration peut faire cesser cette déduction de son salaire par un avis devant être donné dans une certaine période de temps déterminée. Elle est irrévocable quand la procu- ration de l'employé spécifie qu'elle sera valable pour la durée de la convention.

Voilà, exposées en peu de mots, les notions qui sont à la base du problème de la sécurité syndicale. Nous espérons que ces quelques idées, modestement exprimées dans le but d'être utile à tous ceux que préoccupe le problème des relations industrielles, contribueront à jeter quelque lumière sur les débats actuels et à apporter certains éléments à la solution des conflits de travail.

Gerard Dion.

\section{THE FUTURE OF EMPLOYERS' ASSOCIATIONS}

Syndicalism is growing rapidly in Canada. In fact, figures show that the membership of labour associations has increased by more than $85 \%$ since the beginning of the war. In connection with this development of syndicalism, the labour legislation has undergone many a change, namely with the adoption of the principle of compulsory bargaining. However, it is the belief, in certain centres, that workers only are benefitting by laws that advocate professional organizing.

This is untrue. Our labour legislation favours the association of employers as much as that of employees and calls for the undivided collaboration of Capital and Labour. If wage-earners, to-day, stand better united than employers, when it comes to the discussion of industrial problems, it is the employers' fault.

We must admit that some professional associations of employers are now in existence, but it seems that these bodies give far more importance to matters of technical or commercial nature than to the problem of industrial relations. Too many employers are convinced that they can personally establish sound relations between themselves and their workers !

Great headway has been made in that direction, however, during the past few years. Some employers' associations have formed special committees charged with the study of relations between Capital and Labour. This initiative is worthy of note and encouragement. Employers are thus given the opportunity of becoming better acquainted with our labour legislation and of knowing of their duties equally as well as of their rights, and when the time comes to meet with syndicates to negotiate collectively, they can avoid mistakes that would otherwise menace the stability and progress of their enterprise.

Employers should not hesitate to rally to a good association. The more syndicalism will develop among them, the more it will be possible to give juridical extension to working conditions and thus come to the uniformization of working hours and wages in each particular industry. Employers conscious of their social responsibilities will then be protected against a minority group not too interested in the community's welfare.

It is to be hoped that employers' associations will develop as much as workers' unions.

\section{Jean-Pigrre Despres.}

